慶應義塾大学学術情報リポジトリ

Keio Associated Repository of Academic resouces

\begin{tabular}{|c|l|}
\hline Title & $\begin{array}{l}\text { Sitosterol-stimulative production of plasminogen activator in cultured endothelial cells from } \\
\text { bovine carotid artery }\end{array}$ \\
\hline Sub Title & \\
\hline Author & $\begin{array}{l}\text { 萩原, 啓実(Hagiwara, Hiromi) } \\
\text { 下仲, 基之(Shimonaka, Motoyuki) } \\
\text { 森崎, 益雄( Morisaki, Masuo) } \\
\text { 池川, 信夫(Ikekawa, Nobuo) } \\
\text { 稲田, 裕二(Inada, Yuji) }\end{array}$ \\
\hline Publisher & 共立薬科大学 \\
\hline Publication year & 1984 \\
\hline Jtitle & $\begin{array}{l}\text { 共立薬科大学研究年報 (The annual report of the Kyoritsu College of } \\
\text { Pharmacy). No.29 (1984. ),p.37-37 }\end{array}$ \\
\hline JaLC DOI & \\
\hline Abstract & \\
\hline Notes & 抄録 \\
\hline Genre & Technical Report \\
\hline URL & https://koara.lib.keio.ac.jp/xoonips/modules/xoonips/detail.php?koara_id=AN00062898-0000002 \\
\hline & $9-0037$ \\
\hline
\end{tabular}

慶應義塾大学学術情報リポジトリ(KOARA)に掲載されているコンテンツの著作権は、それぞれの著作者、学会または出版社/発行者に帰属し、その権利は著作権法によって 保護されています。引用にあたっては、著作権法を遵守してご利用ください。

The copyrights of content available on the KeiO Associated Repository of Academic resources (KOARA) belong to the respective authors, academic societies, or publishers/issuers, and these rights are protected by the Japanese Copyright Act. When quoting the content, please follow the Japanese copyright act. 


\title{
Sitosterol-Stimulative Production of Plasminogen Activator in Cultured Endothelial Cells From Bovine Carotid Artery*
}

\author{
H. Hagiwara**, M. ShimonaKa**, M. Morisaki**, \\ N. IKEKAWA** and Y. INADA** \\ 萩原啓実 ${ }^{* *}$, 下仲基之**, 森崎益雄, 池川信夫**, 稲田裕二**
}

The endothelial cell is a rich source of plasminogen activator that is associated with fibrinolytic activity in blood vessel. Addition of sitosterol to the culture medium of endothelial cells from bovine carotid artery gave to a marked increment in the activity of plasminogen activator. Removal of sitosterol from the culture medium resulted in a decrease of plasminogen activator activity back to normal levels. Enhancement of plasminogen activator activity in cultured endothelial cells was not observed by cholesterol, 5 -androsten- $3 \beta$-ol and others.

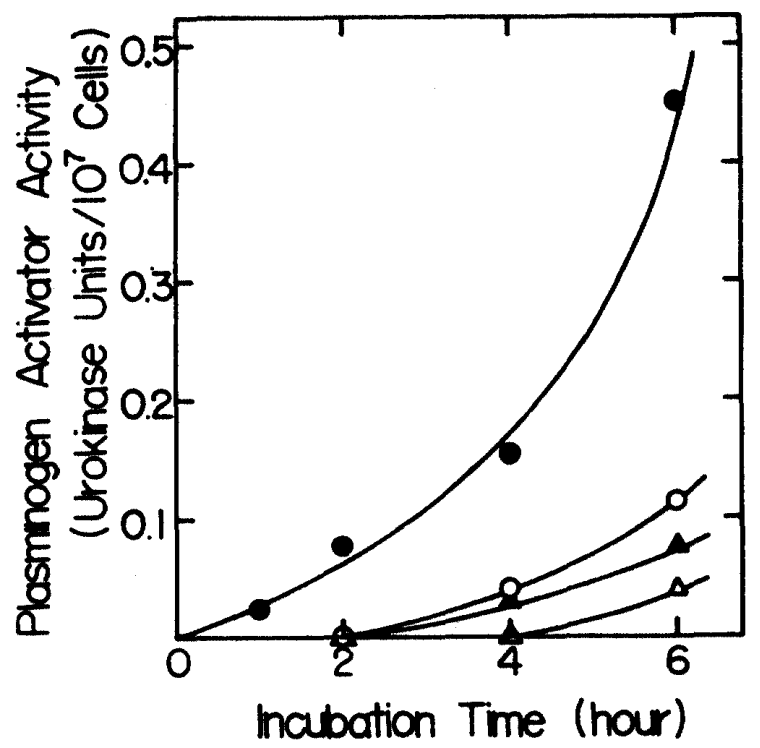

Enhancement of plasminogen activator activity in medium by sitosteroltreated cells.Endothelial cells were subcultured in the presence of $50 \mu \mathrm{M}$ each steroids.

Values are represented as means of values obtained from two different samples. Sitosterol-treated (-O-), untreated $\left(-\mathrm{O}^{-}\right)$, cholesterol $\left(-\mathbf{A}^{-}\right)$, and 5 -androsten-3 $\beta$-ol $(-\triangle-)$.

* 本報告は Thrombosis Res., 33, 363 (1984) に発表

** 東京工業大学理学部 